\title{
Disintegrins from the Venom of Vipera ammodytes ammodytes Efficiently Inhibit Migration of Breast Cancer Cells
}

\author{
Zorica Latinović, ${ }^{1,2}$ Adrijana Leonardi, ${ }^{1}$ Toni Petan, ${ }^{1}$ Margareta Žlajpah ${ }^{1}$ \\ and Igor Križaj* \\ ${ }^{1}$ Department of Molecular and Biomedical Sciences, Jožef Stefan Institute, Jamova cesta 39, Ljubljana, Slovenia \\ ${ }^{2}$ Jožef Stefan International Postgraduate School, Jamova cesta 39, Ljubljana, Slovenia \\ * Corresponding author: E-mail: igorkrizaj@ijs.si \\ Phone: +3861477 3626. Fax: +38614773984.
}

Received: 15-09-2016

For Cutting Edge 2017

\begin{abstract}
Integrins are plasma membrane proteins, whose dysfunction frequently results in cancer pathology, and therefore they represent important targets of anti-tumour therapy. Snake venoms are a rich source of disintegrins (Dis), proteins that specifically bind integrins and thus interfere with their functions. In an attempt to discover new molecules for treatment of breast cancer, the major type of cancer in women, we isolated a dimeric Dis (Vaa-Dis) from the venom of the nosehorned viper. By cell viability testing we demonstrated that $50 \mathrm{nM}$ and higher concentrations of Vaa-Dis were toxic to highly invasive human breast adenocarcinoma cell line MDA-MB-231. Wound-healing assay revealed that already at one order of magnitude lower concentrations Vaa-Dis efficiently inhibited MDA-MB-231 cell migration. This exposed a promising anti-metastatic potential of $\mathrm{Vaa}$-Dis and a good perspective of these natural snake venom proteins for further research and development towards the application in breast cancer treatment.
\end{abstract}

Keywords: snake venom, disintegrin, integrin, cancer, metastasis, drug

\section{Introduction}

Cancer, one of the deadliest diseases worldwide, is caused by inherited or acquired mutations of the genetic material. The main characteristics of cancer include sustaining proliferative signalling, evading growth suppressors, resisting cell death, enabling replicative immortality, inducing angiogenesis, and activating invasion and metastasis. Such properties enable cancer cells an unlimited growth and spreading, invasion through the organism and finally causing its death. ${ }^{1}$ Prevention of metastatic growth is an efficient therapy in cancer control. The key roles in the process of migration and cell viability are played by transmembrane proteins called integrins. ${ }^{1,2}$

Integrins are cell adhesion receptors on the cells' surface that bind components of the extracellular matrix (ECM), various biological ligands and receptors on adjacent cells. They are heterodimeric proteins consisting of one $\alpha$ - and one $\beta$-subunit. 18 different $\alpha$-subunits and $8 \beta$ subunits are known, which have been found to appear in 24 different $\alpha-\beta$ combinations, each of them possessing unique binding specificity. ${ }^{2}$ Recent studies have exposed integrins as important factors in tumour cell survival, tumour growth and metastasis by establishing and breaking bonds between malignant cells and molecules in their surroundings. For this reason, integrins have become important targets of anti-tumour therapy. ${ }^{2}$ Despite the fact that several therapeutics, integrin antagonists, have already been developed, a search for more efficient integrin-binding substances continues. ${ }^{2-4}$

Snake venom (SV) proteins are broadly investigated as substances that can be used in diagnosis and treatment of human diseases. Among them, disintegrins (Dis) have been found to inhibit various cell functions by their interaction with different integrins, for example platelet aggregation, angiogenesis, tumour growth and metastasis. ${ }^{5}$ 
Dis are non-enzymatic cysteine-rich polypeptides. Their molecular mass ranges between $4 \mathrm{kDa}$ and $15 \mathrm{kDa}$. They can be directly synthesized or formed by proteolysis of the P-II class metalloproteinases (MPs). SV Dis can be monomeric or dimeric, hetero- or homodimeric. In dimeric Dis, individual subunits are interconnected by disulphide bonds, which is crucial for stability and maintenance of a distinct globular structure. Dimerization also defines the configuration of the so called inhibitory loop, essential for the interaction with integrin receptor and, consequently, the biological activity. ${ }^{6,7}$

In this work we focused on Dis from the venom of Vipera ammodytes ammodytes (Vaa-Dis). They were purified and biochemically characterized. We investigated their influence on cell viability and in vitro migration in a model of highly invasive triple-negative breast cancer and found that Vaa-Dis potently inhibited the migration of cancer cells.

\section{Material and Methods}

\section{1. Purification of Vaa-Dis}

Raw Vaa venom was obtained from the Institute of Immunology, Zagreb, Croatia. Lyophilized venom was stored at $-20{ }^{\circ} \mathrm{C}$ and before use dissolved in $50 \mathrm{mM}$ Tris, $2 \mathrm{mM} \mathrm{CaCl}_{2}, 300 \mathrm{mM} \mathrm{NaCl}, \mathrm{pH} 7.0$ (buffer A). $250 \mu \mathrm{l}$ of the raw $\mathrm{Vaa}$ venom solution $(16.67 \mathrm{mg})$ was applied on a Superdex 75 column 10/300 (GE Healthcare BioSciences $\mathrm{AB}$, Sweden), equilibrated in buffer $\mathrm{A}$ and attached on a FPLC ÄKTA system (Amersham Biosciences, UK). Gel chromatography was performed at a constant flow rate of $0.5 \mathrm{ml} / \mathrm{min}$. Concentration of proteins in the mobile phase was followed by measuring the absorbance at $280 \mathrm{~nm}$ $\left(\mathrm{A}_{280}\right)$. The $\mathrm{B} 2$ fraction was dialysed against $20 \mathrm{mM}$ MES, $2 \mathrm{mM} \mathrm{CaCl}_{2}, \mathrm{pH} 6.5$ (buffer B) and further fractionated on a SP Sepharose Fast Flow column (GE Healthcare BioSciences AB, Sweden). Bound material was eluted by addition of $500 \mathrm{mM} \mathrm{NaCl}$ in buffer B. The material not retained by the cation-exchanger was collected and separated by reverse phase-high performance liquid chromatography (RP-HPLC) on a PLRP-S column $(4.6 \mathrm{~mm} \times 150$ $\mathrm{mm} ; 2.7 \mu \mathrm{m} ; 120 \AA$, Agilent Technologies, USA), equilibrated with $0.1 \%(\mathrm{v} / \mathrm{v})$ trifluoroacetic acid (TFA) in water (solvent A), at a flow rate of $1 \mathrm{ml} / \mathrm{min}$. The proteins were eluted from the column with a gradient of solvent B $(90 \%$ $(\mathrm{v} / \mathrm{v})$ acetonitrile in $0.1 \%(\mathrm{v} / \mathrm{v})$ TFA in water) as follows: $0-45 \%$ in $13 \mathrm{~min}$ and $45-55 \%$ in $10 \mathrm{~min} . \mathrm{A}_{215}$ was monitored to locate proteins in fractions, which were collected manually. Samples were dried using a vacuum concentrator SpeedVac (Savant, USA).

\section{2. SDS-PAGE Analysis}

Venom samples were analysed using $15 \%(\mathrm{~m} / \mathrm{v})$ polyacrylamide gels in the presence of SDS (SDS-PAGE) un- der non-reducing and reducing conditions according to Laemmli. ${ }^{8}$ Proteins in gels were visualized by PageBlue $^{\mathrm{TM}}$ (Thermo Scientific, USA) as instructed by the manufacturer. Molecular mass standards were from Fermentas (Lithuania).

\section{3. N-terminal Amino Acid Sequence Analysis}

Proteins were N-terminally sequenced by automated Edman degradation on a Procise 492A protein sequencing system (Applied Biosystems, USA).

\section{4. Culturing of MDA-MB-231 Cells}

To carry out the migration assays the highly invasive breast cancer cell line MDA-MB-231 (ATCC, USA) was used. Cells were grown in RPMI-1640 medium (Invitrogen, USA) supplemented with $10 \%$ (v/v) fetal bovine serum (FBS) at $37^{\circ} \mathrm{C}$ in an atmosphere of $5 \%(\mathrm{v} / \mathrm{v}) \mathrm{CO}_{2}$. Adherent cell monolayers were routinely cultured in $\mathrm{T} 25$ and T75 tissue culture flasks (Corning, USA) and passaged in ratios of $1: 3$ to $1: 4$.

\section{5. Cell Viability Testing}

The in vitro cytotoxic potency of Vaa-Dis was evaluated using the PrestoBlue ${ }^{\mathrm{TM}}$ viability assay (Invitrogen, USA) essentially as described previously. ${ }^{9}$ Cells were trypsinized and counted by Trypan blue (Thermo Scientific, USA) exclusion assay ${ }^{10}$ using a hemocytometer (Fortuna, Germany). Cells were seeded in 96-well plates (TPP, Switzerland) at a density of 5000 cells/well in $100 \mu \mathrm{L}$ RPMI-1640 medium and left to attach overnight. Cells were then treated with different concentrations of Vaa-Dis $(0.005 ; 0.05 ; 0.5 ; 5 ; 50 ; 500 \mathrm{nM})$ for $0,24,48$, and $72 \mathrm{~h}$. After the treatment, $10 \mu \mathrm{L}$ of PrestoBlue ${ }^{\mathrm{TM}}$ was added to each well, and the plates were incubated for $30 \mathrm{~min}$ at 37 ${ }^{\circ} \mathrm{C}$. Cell supernatants were transferred to black microtiter plates (Corning, USA) and fluorescence was measured at an excitation of $560 \mathrm{~nm}$ and emission of $590 \mathrm{~nm}$ on an Infinite M1000 microplate reader (Tecan, Switzerland) to determine metabolic activity of the cells. Wells containing only the cell culturing medium and PrestoBlue ${ }^{\mathrm{TM}}$ were used as blank reference standards. Experiments were performed in triplicate. The normalization of cell viability was calculated as the ratio of sample absorbance to control absorbance (cells in media without Vaa-Dis).

\section{6. Wound-healing Assay}

The wound-healing assay (WHA) was used to estimate the potency of Vaa-Dis to inhibit cell migration (anti-migratory potency). MDA-MB-231 cells were trypsinized, counted as specified above and plated in 48-well cell culture dishes (TPP, Switzerland) at a density of $2 \times 10^{5}$ 
cells/well. Wounds (millimetre gaps) were then scratched in each cell monolayer using a pipette tip. Dead cells were removed by washing with D-PBS buffer and solutions of Vaa-Dis in RPMI-1640/10\% FBS at different concentrations $(2.5,5.0,7.5$ and $15.0 \mathrm{nM})$ were added. Control samples contained only media. The influence of Vaa-Dis on cell migration was determined by observing the width of the gap under a CKX41 inverted microscope equipped with an E-450 camera (Olympus, Japan) after 1 h, 6 h, 12 $\mathrm{h}$ and $24 \mathrm{~h}$ of incubation. The gap was analysed using the ImageJ software (Softonic International S.A., Spain). The width of the gap was measured as specified (Suppl. Fig. 1) in three different wells for each concentration and incubation time.

\section{7. Statistical Analysis}

Each experiment was performed in at least three independent repeats. If not stated otherwise, data are presented as a mean percent difference from control with cor-

a)

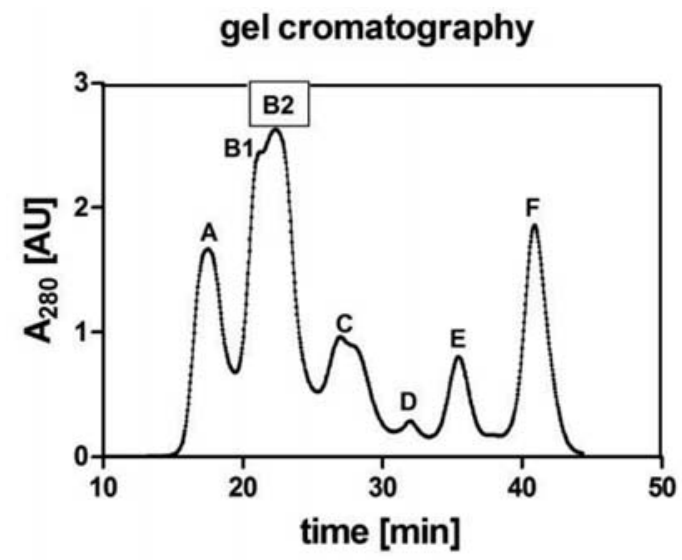

c)

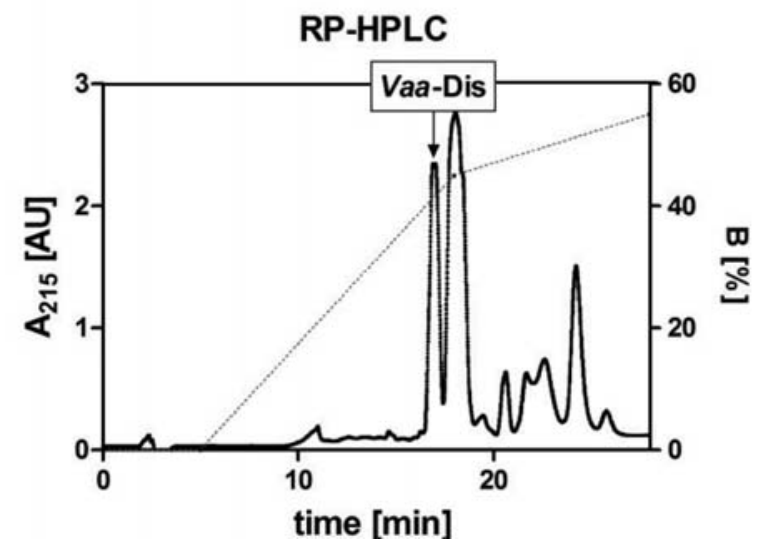

responding standard error of the mean. Statistical tests were run by GraphPad Prism 6 (GraphPad Software Inc., La Jolla, CA, USA) using two-way ANOVA followed by Dunett's multiple comparisons test. Statistical significance is as follows: not significant for $\mathrm{p}>0.05$ (no mark in Fig. 2); significant for $\mathrm{p} \leq 0.05$ (* in Fig. 2), $\mathrm{p} \leq 0.001$ (** in Fig. 2) and $\mathrm{p} \leq 0.0001$ (*** in Fig. 2).

\section{Results and Discussion}

Using gel-filtration chromatography we separated in the first step the raw venom of Vaa into seven fractions (A-F in Fig. 1a). The efficient inhibition of platelet aggregation induced by ADP or collagen by the gel filtration fraction B2 has been suggested to be due to the presence of Dis, which may obstruct this process by binding to $\alpha_{\mathrm{IIb}} \beta_{3}$ fibrinogen receptor. ${ }^{11}$ For this reason, we decided to analyse the fraction B2 further and split it on a strong cation exchanger into a fraction retained by the exchanger

b)

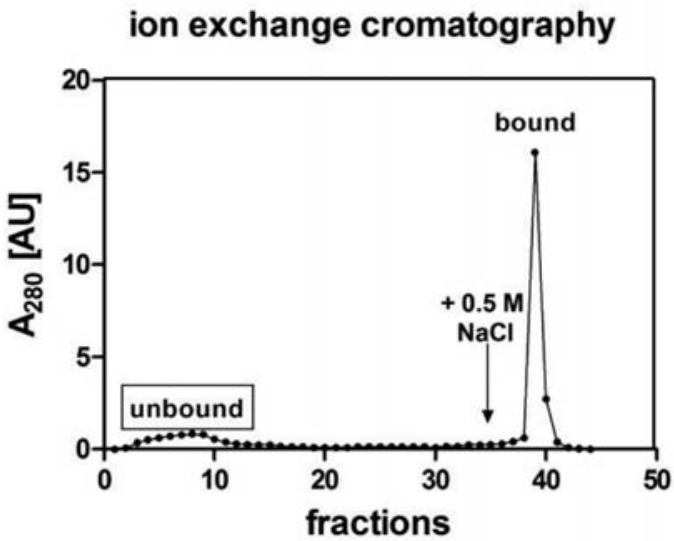

d)

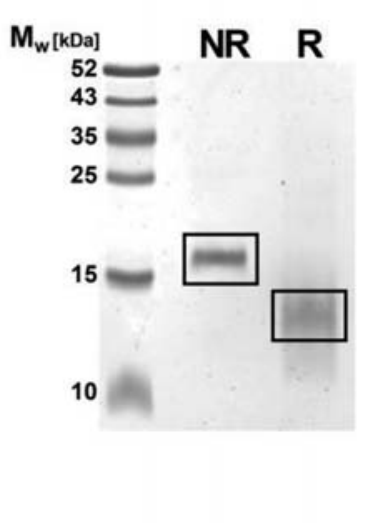

Figure 1: Purification of Dis from the Vaa venom. (a) Using gel filtration on Superdex 75, the raw venom of Vaa was split to seven fractions. Presence of Dis in fraction B2 was indicated by its strong inhibition of platelet aggregation. ${ }^{10}$ (b) Separation of the gel filtration fraction B2 on the SP Sepharose Fast Flow column to column-bound and unbound part. (c) RP-HPLC analysis of the proteins not retained by the SP Sepharose on the PLPR-S column. Vaa-Dis eluted from the column at $40 \%$ of solvent B $(90 \%(\mathrm{v} / \mathrm{v})$ acetonitrile in $0.1 \%(\mathrm{v} / \mathrm{v})$ TFA in water). Dotted line designates the gradient, while full line the absorbance. (d). SDS-PAGE analysis of Vaa-Dis under non-reducing (NR) or reducing (R) conditions revealed the presence of only one protein band. The gel was stained by PageBlue ${ }^{\mathrm{TM}}$. 
(bound) and a flow-through fraction (unbound) (Fig. 1b). The latter was chromatographed on an RP-HPLC column. Vaa-Dis was found in a sharp peak eluting at $40 \%$ of solvent B (Fig. 1c). SDS-PAGE analysis of this peak under non-reducing conditions revealed only one protein band of about $17 \mathrm{kDa}$. Under reducing conditions the protein displayed a lower apparent molecular mass of about $13 \mathrm{k}$ Da (Fig. 1d). This was expected as the usual structure of Viperidae Dis is a cystine-crosslinked dimer, ${ }^{6,8}$ which dissociates to monomers in the presence of reducing agents. The homogeneity of Vaa-Dis sample was inspected by Nterminal amino acid sequencing using Edman degradation. Two N-terminal sequences, NSANP and NSGNP, were obtained, both characteristic for Dis. ${ }^{12}$ Considering also the SDS-PAGE analysis, this means that the Vaa-Dis sample did not contain any non-Dis protein. The heterogeneous N-terminal sequence of the sample indicates that Vaa-Dis is either a heterodimer or a mixture of two homodimeric Dis proteins. Calvete et al. reported about VA6, a homodimeric Dis from the venom of Vipera ammodytes with the N-terminal sequence NSANP identical to one of the sequences that we have found in our sample. ${ }^{12}$ This is a hint that our sample may consist of two homodimeric rather than one heterodimeric Dis. VA6 is an RGD motifcontaining Dis. ${ }^{5,10}$ It has been demonstrated that such Dis efficiently bind to $\alpha_{\mathrm{II}} \beta_{3}$ receptor on platelets and in this way inhibit platelet aggregation. ${ }^{12}$ The observed inhibition of ADP- and collagen-induced platelet aggregation by the Vaa venom gel filtration fraction $\mathrm{B} 2^{11}$ thus also suggests the same interpretation of our results.

Some RGD-containing Dis have been demonstrated to inhibit $\alpha_{v} \beta_{3}$ (vitronectin receptor)-mediated migration of endothelial and cancer cells - two examples of such SV Dis are triflavin and DisBa-01. ${ }^{13}$ As one of our main research topics is discovering new substances to oppose breast cancer, the major cause of death in women population worldwide, ${ }^{14}$ the possibility that Vaa-Dis also affects the migration of cancer cells directed our subsequent experiments. To this end, resolving the question of whether $\mathrm{Vaa}$-Dis is a heterodimeric Dis or a mixture of two homodimeric Dis was secondary so we did not go further to answer it. We study metastatic breast cancer on a model cell line, highly invasive human breast adenocarcinoma MDA-MB-231 cells. We found that Vaa-Dis is not cytotoxic to these cells at concentrations lower than $50 \mathrm{nM}$ (Fig. 2a). At $50 \mathrm{nM}$ and higher concentrations, Vaa-Dis induced a significant drop in cell viability, possibly by effecting proliferation and/or dying of the cells. Both processes are namely regulated via integrins, ${ }^{2,4}$ which are present in higher amounts in cancer cells than in the healthy cells. ${ }^{5}$ The level of expression of integrins $\alpha_{v} \beta_{3}, \alpha_{v} \beta_{5}, \alpha_{5} \beta_{1}, \alpha_{6} \beta_{4}$, $\alpha_{4} \beta_{1}$ and $\alpha_{v} \beta_{6}$ has been found in positive correlation with the ability of cells to migrate. ${ }^{13}$ In MDA-MB-231 cells the integrin $\alpha_{\mathrm{v}} \beta_{5}$ and $\alpha_{\mathrm{v}} \beta_{3}$ are particularly highly expressed. ${ }^{13}$ Drugs should not be toxic to healthy cells therefore the effect of Vaa-Dis on migration of cancer cell was evaluated at sub-cytotoxic concentrations of Vaa-Dis. As evident from the WHA results presented in Suppl. Fig. 1 and Fig. $2 \mathrm{~b}$, Vaa-Dis significantly slowed down the in vitro migration of MDA-MB-231 cells already at the concentration of $2.5 \mathrm{nM}$, well below concentrations at which cytotoxic effects were detected (Fig. 2a) and in the same concentration range as rhodostomin, triflavin and trigramin, all SV Dis. $^{15}$
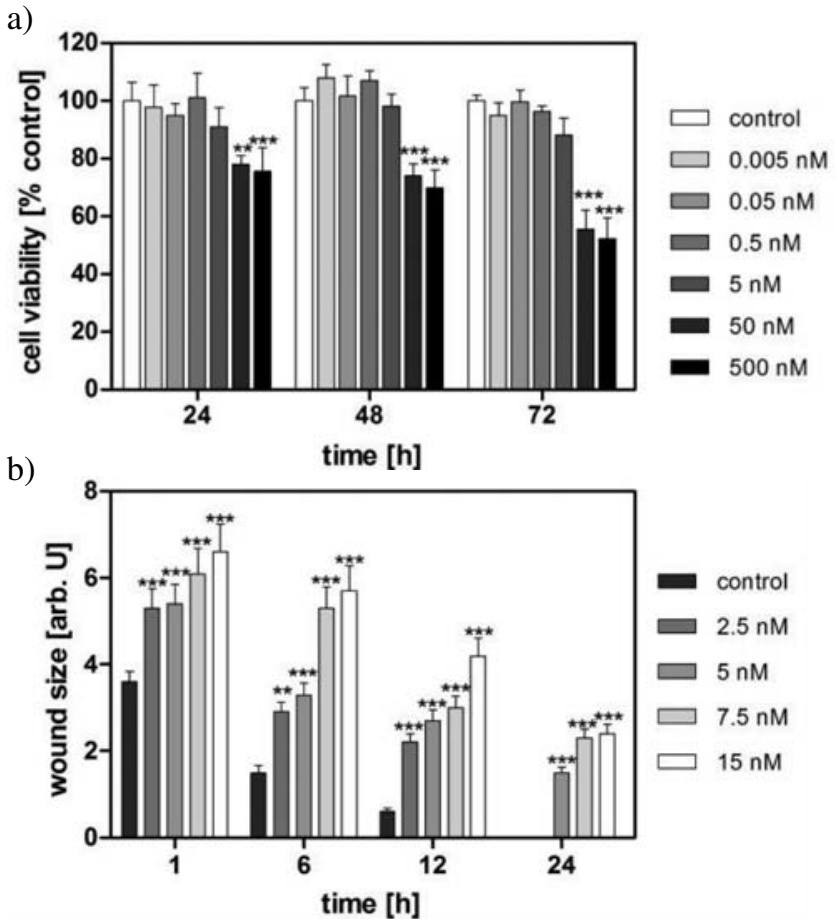

Figure 2: Effects of Vaa-Dis on breast cancer cells. (a) As established by PrestoBlue ${ }^{\mathrm{TM}}$ cell viability testing, the cytotoxicity of Vaa-Dis for MDA-MB-231 cells is evident at $50 \mathrm{nM}$ and higher concentrations. Each result is an average of three independent experiments. (b) The wound-healing assay on MDA-MB-231 cells was performed in the presence of Vaa-Dis at concentrations, which did not affect cell viability. Each result is an average of three independent experiments. Units are arbitrary (arb. U). Statistical significance is displayed as follows: no mark for $p>0.05$ (not significant), $*$ for $\mathrm{p} \leq 0.05, * *$ for $\mathrm{p} \leq 0.001$ and $* * *$ for $\mathrm{p} \leq 0.0001$.

\section{Conclusions}

We have described the isolation and characterisation of novel Dis from the venom of Vaa. Due to a potent cancer cell anti-migratory activity, Vaa-Dis sample is promising for further research and development towards the use in breast cancer therapy.

\section{Acknowledgements}

This work was supported by the grant from the Slovenian Research Agency (P1-0207). We are grateful to Klemen Strojan (M.Sc., Faculty of Electrical Engineering, 
University of Ljubljana) for the help with the statistical analysis of cell culture data and Petra Malavašič (M.Sc., Department of Molecular and Biomedical Sciences, Jožef Stefan Institute) for the help with cell culture experiments.

\section{References}

1. D. Hanahan, R. A. Weinberg, Cell. 2011, 144, 646-674. https://doi.org/10.1016/j.cell.2011.02.013

2. L. Seguin, J. S. Desgrosellier, S. M. Weis, D. A. Cheresh, Trends Cell Biol. 2015, 25, 234-40. https://doi.org/10.1016/j.tcb.2014.12.006

3. A. M. Alizadeh, S. Shiri, S. Farsinejad, Tumour Biol. 2014, 35, 8483-8523. https://doi.org/10.1007/s13277-014-2421-z

4. J. S. Desgrosellier, D. A. Cheresh, Nat. Rev. Cancer 2010 , 10, 9-22. https://doi.org/10.1038/nrc2748

5. J. K. Arruda Macêdo, J. W. Fox, M. de Souza Castro, Curr. Protein Pept. Sci. 2015, 16, 532-548. https://doi.org/10.2174/1389203716666150515125002

6. J. J. Calvete, Toxicon 2013, 62, 40-49. https://doi.org/10.1016/j.toxicon.2012.09.005
7. J. J. Calvete, L. Sanz, P. Cid, P. de la Torre, M. Flores-Díaz, M. C. Dos Santos, A. Borges, A. Bremo, Y. Angulo, B. Lomonte, A. Alape-Girón, J. M. Gutiérrez, J. Proteome Res. 2010, 9, 528-544. https://doi.org/10.1021/pr9008749

8. U. K. Laemmli, Nature 1970, 227, 680-685. https://doi.org/10.1038/227680a0

9. A. Pucer, V. Brglez, C. Payré, J. Pungerčar, G. Lambeau, T. Petan, Mol. Cancer. 2013, 12, 111. https://doi.org/10.1186/1476-4598-12-111

10. W. Strober, Curr. Protoc. Immunol. 2001, Appendix 3, Appendix $3 B$.

11. T. Sajevic, A. Leonardi, I. Križaj, Toxin Rev. 2014, 33, 33-36. https://doi.org/10.3109/15569543.2013.835827

12. J. J. Calvete, M. P. Moreno-Murciano, R. D. G. Theakston, D. G. Kisiel, C. Marcinkiewicz, Biochem. J. 2003, 372, 725-734. https://doi.org/10.1042/bj20021739

13. H. S. Selistre-de-Araujo, C. L. S. Pontes, C. F. Montenegro, A. C. B. M. Martin, Toxins (Basel), 2010, 2, 2606-2621. https://doi.org/10.3390/toxins2112606

14. R. D. Baird, C. Caldas, BMC Med. 2013, 11, 151. https://doi.org/10.1186/1741-7015-11-151

15. R. S. Yang, H. S. Chiang, C. H. Tang, C. S. Yeh, T. F. Huang, Toxicon 2005, 46, 387-393.

https://doi.org/10.1016/j.toxicon.2005.05.002

\section{Povzetek}

Integrini so proteini v plazemski membrani celic. Nepravilno delovanje teh proteinov lahko vodi v nastanek tumorjev, zato so pomembna tarča protitumorskih terapij. Disintegrini (Dis) so proteini iz kačjega strupa, ki se specifično vežejo na integrin in s tem ovirajo njihovo normalno delovanje. $\mathrm{Z}$ namenom odkrivanja novih molekul za terapijo raka dojke, najbolj razširjene vrste raka pri ženskah, smo iz strupa modrasa izolirali dimerni Dis (Vaa-Dis). Izmerili smo vpliv VaaDis na viabilnost celic celične linije visoko invazivnega adenokarcinoma dojke MDA-MB-231 in ugotovili, da je bil Vaa-Dis v koncentracijah, višjih od $50 \mathrm{mM}$, za celice toksičen. Test celjenja celične rane, s katerim smo preverili vpliv Vaa-Dis na migracijo celic, pa je pokazal, da je Vaa-Dis učinkovito upočasnil migracijo rakavih celic že pri koncentracijah, ki so bile za en velikostni red nižje. Dobljeni rezultati potrjujejo antimetastatski potencial Vaa-Dis in predstavljajo dober obet za nadaljnji razvoj teh molekul iz kačjega strupa v smeri priprave novih učinkovin za zdravljenje raka dojke. 